\title{
Evaluation of the time of concentration estimation methods for small rural watersheds
}

\author{
$\underline{\text { Bruna Nogueira Rezende }}^{\text {a }}$ (D), Vassiliki T. G. Boulomytis ${ }^{\text {a,b,c }}$ (D), Sérgio Nascimento Duarte ${ }^{\text {a }}$ (D), \\ Marco Antonio Jacomazzi ${ }^{\mathbf{c}}$ and Antônio Carlos Zuffo ${ }^{c}$ \\ ${ }^{a}$ University of Sao Paulo (USP), College of Agriculture "Luiz de Queiroz”- ESALQ, Department of \\ Biosystems Engineering, Piracicaba, SP, Brazil ${ }^{b}$ Federal Institute of Science, Education and Technology of \\ Sao Paulo - IFSP, Faculty of Civil Engineering, Caraguatatuba, SP, Brazil ${ }^{c}$ State University of Campinas - \\ UNICAMP, School of Civil Engineering, Architecture and Urban Design, Campinas, SP, Brazil \\ Email: bruna.n.rezende@usp.br
}

\begin{abstract}
The time of concentration (tc) is a widely used input parameter for the design of hydrographs, peak flow estimates, and runoff hydrological models. Conceptually, it is the average time it takes for water to flow from the most hydrologically distant location of the watershed to its outlet. The tc varies according to the characteristics of the basin, such as average slope, length and soil infiltration. It can be evaluated by calculating the time elapsed between the moment the effective rain stops and the end of the runoff identified by the hydrograph infusion point. When calculating the tc, there are some uncertainties that affect the performance of tc acquisition methods. The tc observations can generally be overestimated if they refer to runoff with a low hydraulic load. Because of that, the regular and effective assessment of watersheds is commonly used to validate the most appropriate tc estimation method. Among the equations used to estimate the tc of a watershed, this study aims to evaluate and compare the performance of twelve empirical and semi-empirical methods in three small rural watersheds in the state of São Paulo, Brazil. All watersheds had smaller areas than $81 \mathrm{~km}^{2}$ and none of them are assessed. The tc estimates of the different models ranged between $1.08 \mathrm{~h}$ and $15.19 \mathrm{~h}$, $1.00 \mathrm{~h}$ and $17.23 \mathrm{~h}$, and $0.80 \mathrm{~h}$ and $8.20 \mathrm{~h}$ for the Barreiro, Copaiba and Lambari watersheds, respectively. The lowest tc value was estimated by the DNOS method and the longest one by the SCS Lag method for the Barreiro and Lambari watersheds. For Copaiba watershed, the lowest tc value was estimated by the DNOS method as well, but the highest tc value was derived by the Venturi equation. The tc estimates for the Lambari watershed were about twice higher than those of Copaiba watershed, although their areas were approximately similar. This difference among the estimates was strongly influenced by the explanatory variable of the thalweg models, followed by the mean slope. The results revealed that among the analysed formulas, the DNOS, Kirpich and Picking methods showed great similarity for presenting the smallest tc, causing the design of larger control structures. The SCS Lag and the Kinematic Wave method presented the highest tc, which can lead to lack of safety in hydraulic structures.
\end{abstract}

Keywords: Rural watersheds, time of concentration, uncertainty, land use and land cover 


\section{INTRODUCTION}

For the design of hydraulic works and use of water resources it is necessary to determine what the available discharge is. In this sense, the effective discharge derivation depends on the proper estimation of the watershed time of concentration (tc) The tc of a watershed can be defined as the time required for rainwater falling upon its most hydrologic distant region to runoff to its outlet (Tucci et al. 2009; Targa et al. 2012). In other words, it is the average time for water to reach the outlet as there is some dispersion throughout the watershed.

According to Araujo et al. (2011), factors such as basin area geometry, average terrain slope, sinuosity, soil infiltration, thalweg slope, among others, affect the time of concentration. Aiming to extend the knowledge about tc, several studies have been carried out in different locations in which distinct empirical equations and methods have been used.

The determination of the tc using empirical formulas is subject to the inaccuracies and uncertainties due to the type of flow that the formula seeks to represent. Consequently, continuous and appropriate hydrological monitoring is fundamental to validate the tc estimation of watersheds (Almeida et al. 2014, Boulomytis et al. 2017).

Several researchers have developed empiric equations based on experimental and analytic methods to estimate the tc (Kirpich 1940; Dooge 1956; Chow1962). One of the most common empirical formulations in studies of this nature is the Kirpich method (Araujo et al. 2011). Although it is only applicable to very small watersheds (Kirpich 1940), in practice it is often used for watershed with a single main stream.

Because such numerous different equations, establishing a single and reliable estimation method for calculating the tc becomes a challenge. The lack of possibility to perform direct measurements contributes to this scenario of multiple choices (Maia 2020).

In the current perspective, parameter options for calculating tc can be estimated using more technologically advanced tools, such as the Geographic Information Systems (GIS). The GIS has useful tools to model information related to the hydrological factors of watersheds. It can be applied to subside the estimation of the surface runoff of watersheds and also calculation of hydrological groups, land use and land cover (LULC), previous soil moisture, and hydrological conditions that can be applied at the runoff Curve Number Method (Nasiri and Alipur 2014).

In this sense, this work aims to estimate the tc of three small rural watersheds in the State of Sao Paulo using the ArcGIS software and twelve methods: Kinematic Wave, FAA, Kirpich, SCS Lag, Pasini, Ventura, DNOS, George Ribeiro, Ven te Chow, Johnstone, Corps of Engineers and Picking.

\section{METHODOLOGY}

\subsection{Study area}

We conducted the present work in three small rural watersheds (Barreiro, Lambari and Copaiba) within the Paraná basin located in the municipalities of Guzolandia, Casa Branca and Bastos, State of Sao Paulo, comprising areas of $80.35 \mathrm{~km}^{2}, 66.98 \mathrm{~km}^{2}$ and $65.30 \mathrm{~km}^{2}$, respectively (Figure 1).

\subsection{Land use and land cover}

The assessment of LULC information in these basins has been carried out based on MapBiomas (2020) regarding the data of 2019. We used the satellite images collected from LANDSAT 8 with spatial resolution of $30 \mathrm{~m}$.

After the classification of MapBiomas imagery, we brought together some land use and land cover classes and renamed them due to their similar behaviour taking into consideration their hydrological features. For instance: the class "Farmland Formation" was grouped with the "Savannah Formation" class; the "Agriculture and Pasture" class was grouped with the "Pasture" class; and the class "Other non-vegetated area" was renamed to "Exposed Soil". 


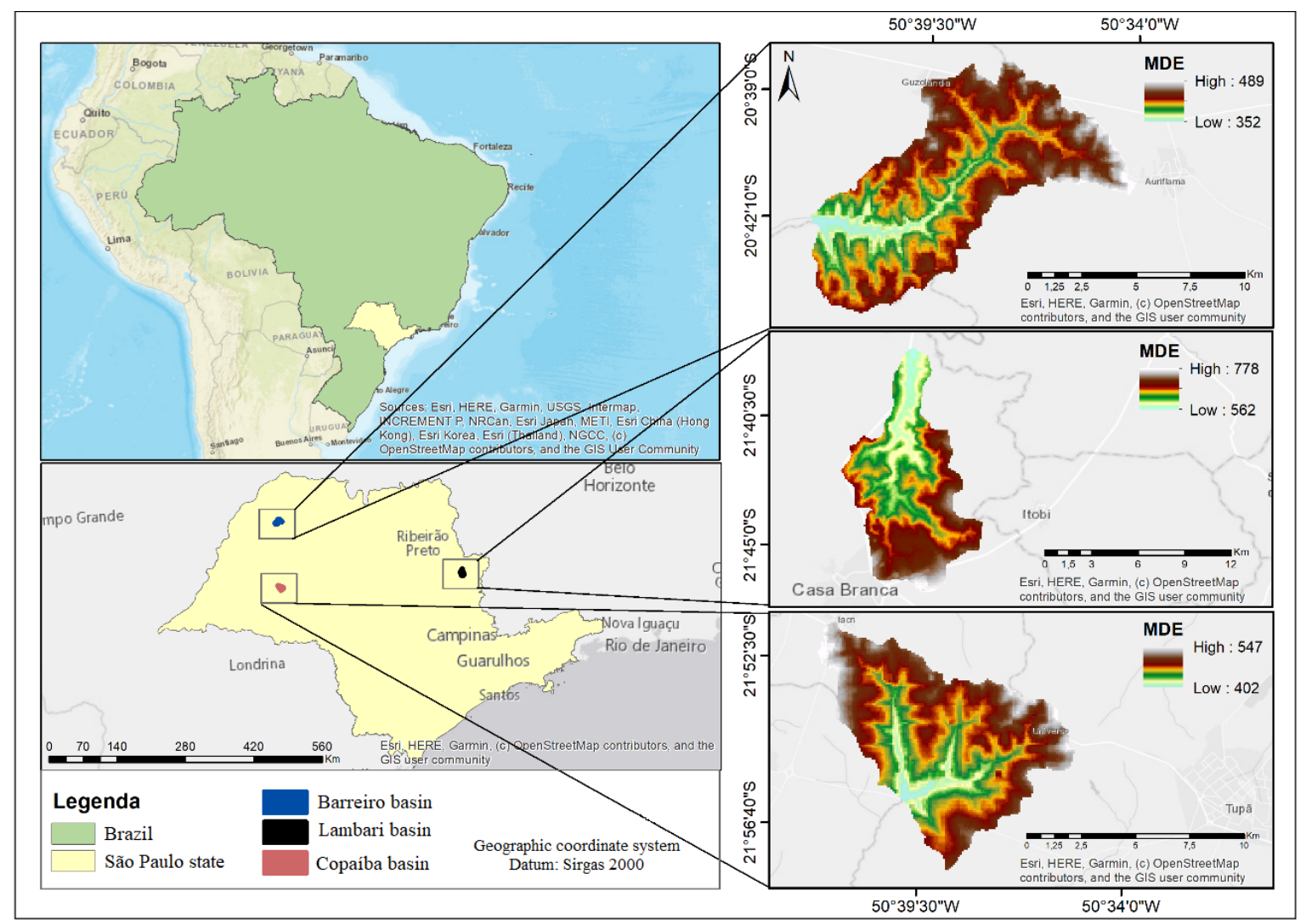

Figure 1. Spatial location of Barreiro, Lambari and Copaiba watersheds in the State of Sao Paulo, Brazil.

\subsection{Time of concentration calculation}

Twelve empirical and semi empirical methods were selected to calculate the times of concentration of the watersheds after an in-depth literature review. For the selection of methodologies, appropriate equations for rural watersheds were prioritized (Silveira 2005). To calculate the tc (h), we used the following methods: Kinematic Wave, FAA, Kirpich, SCS Lag, Pasini, Ventura, DNOS, George Ribeiro, Vent Chow, Johnstone, Corps of Engineers and Picking (Table 1).

Table 1. Estimation methods used for the time of concentration.

\begin{tabular}{|c|c|}
\hline Nome & Fórmula \\
\hline Kinematic wave & $t c=7,35 n^{0,6} i^{-0,4} L^{0,6} S^{-0,3}$ \\
\hline FAA & tc $=0,37(1,1-C) L^{0,5} S^{-0,333}$ \\
\hline Kirpich & $\mathrm{tc}=0,0663 L^{0,77} S^{-0,385}$ \\
\hline SCS Lag & tc $=0,057(1000 / \mathrm{CN}-9)^{0,7} L^{0,8} S^{-0,5}$ \\
\hline Ven te Chow & $\mathrm{tc}=0,160 L^{0,64} S^{-0,32}$ \\
\hline Johnstone & $\mathrm{tc}=0,462 L^{0,5} S^{-0,25}$ \\
\hline Corps of Engineers & $\mathrm{tc}=0,191 L^{0,76} S^{-0,19}$ \\
\hline Pasini & $\mathrm{tc}=0,107 A^{0,333} L^{0,333} S^{-0,5}$ \\
\hline Ventura & $\mathrm{tc}=0,127 A^{0,5} S^{-0,5}$ \\
\hline Picking & $\mathrm{tc}=0,0883 L^{0,667} S^{-0,333}$ \\
\hline DNOS & $t c=0,419 k^{-1} A^{0,3} L^{0,2} S^{-0,4}$ \\
\hline George Ribeiro & $\mathrm{tc}=0,222(1,05-0,2 \mathrm{p})^{-1} L S^{-00,4}$ \\
\hline Source: Adapted from Silveira $(2005)$.
\end{tabular}

The parameters required for the tc calculation were prepared in a GIS environment using the ArcGIS Desktop v.10.8 software. They were the area $\left(\mathrm{A}\right.$ in $\left.\mathrm{km}^{2}\right)$, thalweg length ( $\mathrm{L}$ in Kilometers) and slope $(\mathrm{S}$ in $\mathrm{m} / \mathrm{m})$. We adopted the rainfall intensity $35 \mathrm{~mm} / \mathrm{h}$ according to McCuen et al. (1984). We obtained the values of the Manning's roughness coefficient, C parameter, the $\mathrm{k}$ factor of DNOS equation and the $\mathrm{p}$ factor of George 
Ribeiro's equation according to Silveira (2005). The Curve Number (CN) was used by the SCS Lag equation. It was calculated for the three watersheds correlating the hydrological group of soil types and the LULC classes. The assignment of the $\mathrm{CN}$ values for each land cover class was based on the SCS standard table of values. After assigning values, the average $\mathrm{CN}$ values were achieved for each watershed according to its drainage area.

According to the Kinematic Wave, FAA, Kirpich, SCS Lag, Pasini, Ventura, DNOS and George Ribeiro equations, the length (L) must be determined for the source of the river and the slope must be calculated from the ratio between the maximum slope and length of course. On the other hand, Ven te Chow, Johnstone, Corps of Engineers and Picking mention L as the length of the main stream and S as its mean slope (Silveira 2005).

\section{RESULTS AND DISCUSSION}

Due to the LULC that represents the study watersheds, twelve classes were defined: forest formation, savanna formation, flooded field, forest plantation, pasture, sugarcane, soy beans, temporary crops, perennial crops, urban infrastructure, exposed soil and river. Figure 2 shows the LULC of the watersheds and Table 2 shows the watershed areas of each LULC using in 2019 data.

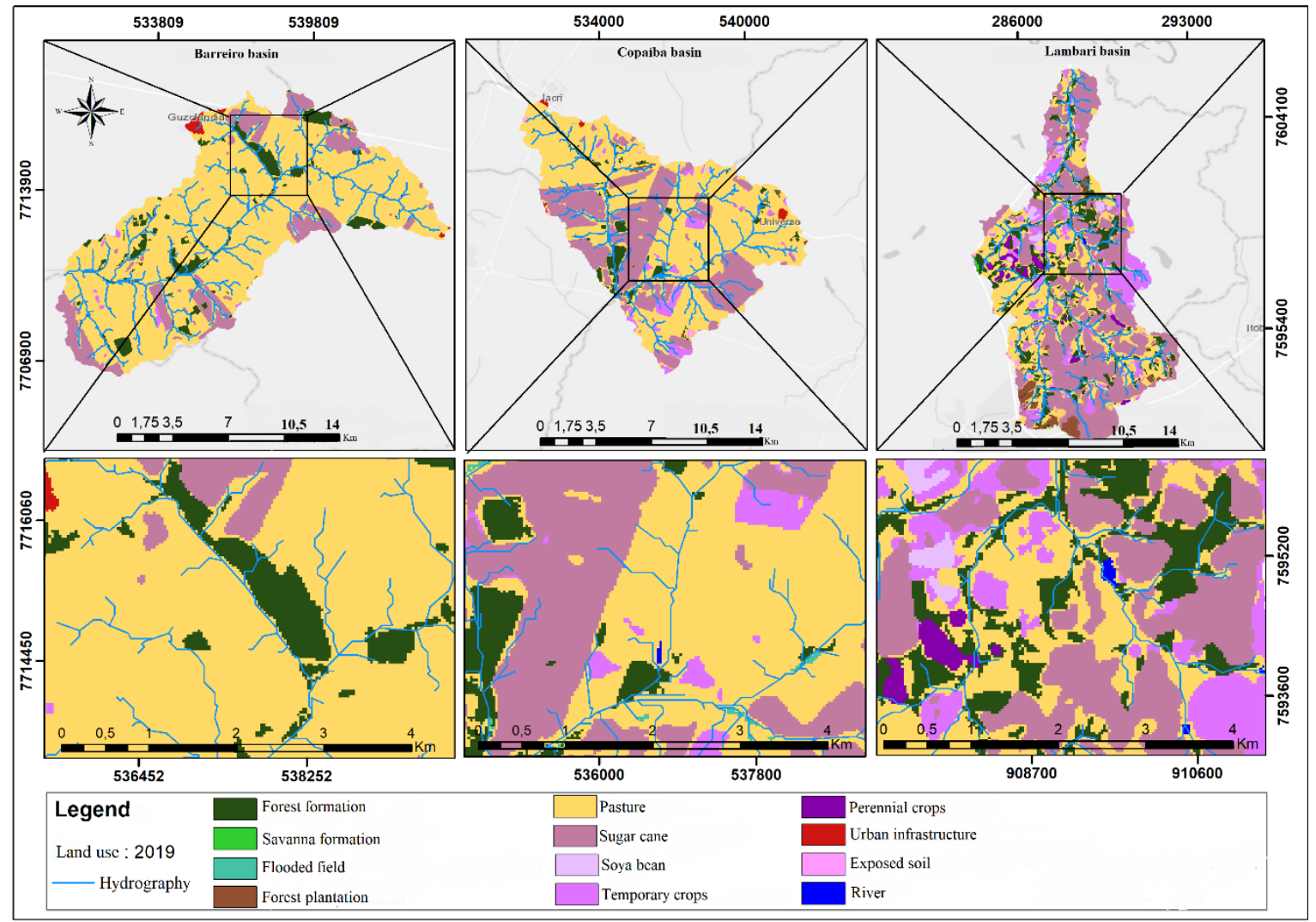

Figure 2. Land use and cover of the Barreiro, Copaiba and Lambari watersheds.

Pasture is the predominant LULC in the Barreiro and Copaiba watersheds, covering the rural areas of approximately $64.38 \mathrm{~km}^{2}(80.12 \%)$ and $41.31 \mathrm{~km}^{2}(63.26 \%)$, respectively. Sugarcane occupies the second largest area of $9.77 \mathrm{~km}^{2}(12.16 \%)$ and $18.32 \mathrm{~km}^{2}(28.06 \%)$ in the respective watersheds. On the other hand, Lambari watershed is mainly covered by sugarcane whose area is $23.80 \mathrm{~km}^{2}$ (i.e. $35.53 \%$ of the total area). Pasture covers an area of $22.51 \mathrm{~km}^{2}$ corresponding to $33.60 \%$ in this wathershed.

The areas covered by natural vegetation (forest formation, savanna formation and flooded field) represent a smaller contribution to the landscape due to a seculary deforestation, resulting in a large percentage of pasture and agricultural areas in the watersheds.

The watersheds are located on flat and gently undulating terrains consisting of two predominant types of tropical soil: red-yellow argisol (RYA) (in Copaiba and Lambari) and red latosol (RL) (in Barreiro). The RYA soils have been developed under the influence of crystalline rocks, which might have clay accumulation, and presence of iron oxides in subsurface horizons. The RL soils have deep developed profiles, a clayey texture and low natural fertility as their limiting factor. Nevertheless, they are suitable for agricultural and urban activities (Moraes et al. 1994; Pissarra et al. 2004). 
Rezende et al., Evaluation of the time of concentration estimation methods for small rural watersheds

Table 2. Percentage of basin areas classified into LULC.

\begin{tabular}{|c|c|c|c|c|c|c|}
\hline \multirow{2}{*}{ LULC } & \multicolumn{2}{|c|}{ Barreiro } & \multicolumn{2}{|c|}{ Copaiba } & \multicolumn{2}{|c|}{ Lambari } \\
\hline & $\left(\mathrm{km}^{2}\right)$ & $(\%)$ & $\left(\mathrm{km}^{2}\right)$ & $(\%)$ & $\left(\mathrm{km}^{2}\right)$ & $(\%)$ \\
\hline Forest Formation & 5.35 & 6.66 & 2.42 & 3.70 & 8.87 & 13.24 \\
\hline Savanna Formation & - & - & - & - & 0.06 & 0.09 \\
\hline Flooded Field & - & - & 0.28 & 0.43 & - & - \\
\hline Forest plantation & - & - & 0.19 & 0.29 & 1.78 & 2.65 \\
\hline Pasture & 64.38 & 80.12 & 41.31 & 63.26 & 22.51 & 33.60 \\
\hline Sugarcane & 9.77 & 12.16 & 18.32 & 28.06 & 23.80 & 35.53 \\
\hline Soy beans & - & - & 0.03 & 0.04 & 1.33 & 1.98 \\
\hline Temporary Crops & 0.40 & 0.50 & 2.31 & 3.54 & 7.01 & 10.46 \\
\hline Perennial Crops & - & - & - & - & 1,32 & 1.96 \\
\hline Urban Infrastructure & 0.43 & 0.54 & 0.27 & 0.41 & - & - \\
\hline Exposed Soil & 0.01 & 0.01 & 0.15 & 0.24 & 0.24 & 0.36 \\
\hline River & 0.01 & 0.02 & 0.02 & 0.03 & 0.07 & 0.11 \\
\hline Total & 80.35 & 100 & 65.30 & 100 & 66.98 & 100 \\
\hline
\end{tabular}

The $\mathrm{CN}$ values properly represented the physical conditions of each watershed in terms of runoff, infiltration and LULC. The weighed CN values for Copaiba, Barreiro and Lambari watersheds were 64, 61 and 45, respectively. As expected, the highest $\mathrm{CN}$ values are related to the greater number of areas covered by pasture, corroborating to the fact that there is a greater runoff in Copaiba and Barreiro watersheds in relation to Lambari watershed. According to Raminhos (2002), rural watersheds have a higher infiltration capacity due to mainly vegetation cover, which is similar to a macro-roughness effect and thus, provides a higher resistance to runoff.

In Figure 3, we show the tc results, which were calculated by empirical methods. It should be observed that there is a great variability among the obtained values, and two extreme cases. The DNOS and Picking methods presented similar values, which can be explained by the similar parameters contained in their equations. On the other hand, the SCS Lag and Kinematic Wave methods presented the longest time of concentration for the three studied watersheds, which might be related to the fact that these methods incorporate constants on the features of land surface in their equations. These latest two methods have a semi-empirical deduction.

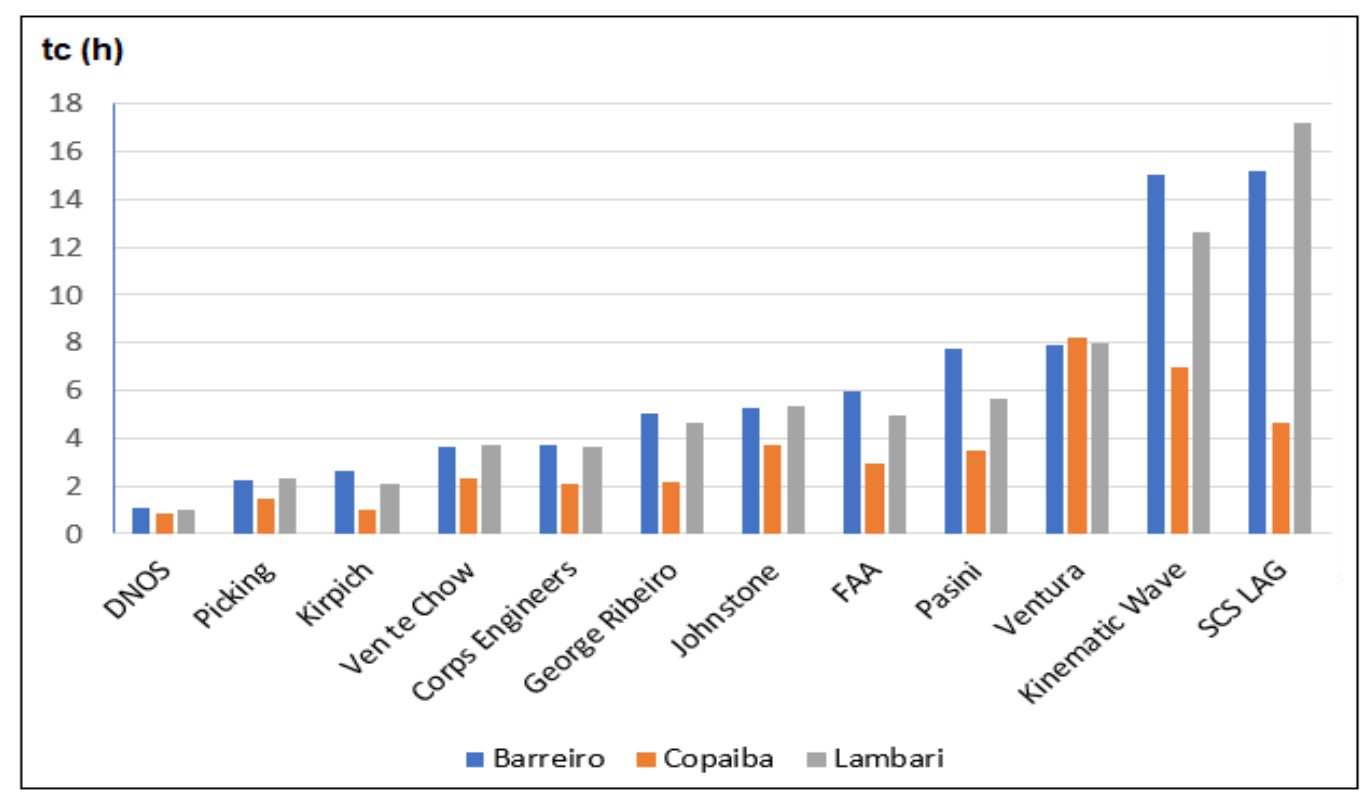

Figure 3. Time of concentration estimated for Barreiro, Lambari and Copaiba watersheds using 12 different methods.

The lowest tc value calculated for the Barreiro watershed was $1.08 \mathrm{~h}$ and the highest was $15.19 \mathrm{~h}$ (i.e. 14 times the lowest value). The mean value was $6.28 \mathrm{~h}$ and the median was $5.87 \mathrm{~h}$, while the coefficient of variation 
(CV) was $73 \%$. The lowest tc value of the Copaiba watershed was $1.00 \mathrm{~h}$, while the highest was $17.23 \mathrm{~h}$, showing the increase of 17 times the lowest value. The mean was $5.93 \mathrm{~h}$ and the median was $4.81 \mathrm{~h}$.

For Lambari watershed, the tc value varied between $0.9 \mathrm{~h}$ and $8.2 \mathrm{~h}$ showing the increase of 10 times the lowest value, the mean of $3.32 \mathrm{~h}$ and the median was $2.62 \mathrm{~h}$. The $\mathrm{CV}$ of the estimated tc for the Copaiba and Lambari watersheds were $70 \%$ and $79 \%$, respectively.

For the three watersheds, the lowest tc value was estimated by the DNOS method and the other two lower values were estimated by the Picking and Kirpich equations. In average, the second and third lowest tc values were approximately twice the value calculated for the DNOS model for the Barreiro and Lambari watersheds. However, for the Copaiba watershed, the mean tc value was $50 \%$ higher than the one achieved from the DNOS model.

The highest tc for the Barreiro and Lambari watersheds were estimated by the SCS Lag model, while for the Copaiba watershed it was the tc value calculated by the Ventura model.

Even though the areas of Copaiba $\left(65.30 \mathrm{~km}^{2}\right)$ and Lambari $\left(66.98 \mathrm{~km}^{2}\right)$ are approximately similar, the respective tc values are totally distinct. It was verified that for the Lambari watershed the tc value was almost twice the value of the ones found for the Copaiba watershed.

Regarding Copaiba watershed, the thalweg length (L) is $8.20 \mathrm{~km}$, ratio between the maximum slope and $\mathrm{L}$ $(\mathrm{M} / \mathrm{L})$ is $0.06 \mathrm{~m} / \mathrm{m}$, and ratio between the maximum slope and the mean slope $(\mathrm{M} / \mathrm{S})$ is $0.0155 \mathrm{~m} / \mathrm{m}$. For Lambari watershed, $\mathrm{L}$ is $17.62 \mathrm{~km}, \mathrm{M} / \mathrm{L}$ is $0.04 \mathrm{~m} / \mathrm{m}$ and $\mathrm{M} / \mathrm{S}$ is $0.0171 \mathrm{~m} / \mathrm{m}$.

The tc estimation is strongly influenced by L, and then, by the slope. For Copaiba and Lambari watersheds, the longest thalweg was determinant for the tc estimation. Besides, the weighed $\mathrm{CN}$ value for Lambari watershed was 45, while for Copaiba it was 64. These values interfered in the tc estimations using the SCS Lag method. Although the tc was almost twice for Lambari watershed, comparing to the others, it was lower than the estimated tc values by the kinematic wave and Ventura for the Copaiba watershed.

Araujo et al. (2011) analysed the tc of watersheds and found that Ven Te Chow and Picking methods presented values which were very close to that obtained by the Kirpich method, even by varying the area and slope. According to Esteves (2003), Kirpich method presented a value close to the tc observed in urban watersheds, as reported by Boulomytis et al. (2017). Kirpich method is the most widely used in simple structures in Brazil. However, the SCS Lag method overestimated tc. Regarding the Kinematic Wave method, Tucci (1993) explains that it tends to overestimate the tc by considering that runoff occurs on a plain watershed, which does not occur in practice where there are slopes. In this latest case, runoff get together after some meters in small ditches on the soil surface.

The water management authorities in Brazil generally use fully empirical equations such as DNOS, Picking and Kirpich, since they can provide greater reliability. Notwithstanding, these formulas can lead to the implementation of very large sized control structures, which can be is not advantageous for rural producers.

\section{CONCLUSION}

The watershed sizes and runoff types are important information to define the most suitable methods for the tc deviation. However, it is still not possible to recommend the most appropriate estimation method for watersheds without considering the observed hydrographs for comparison purposes.

The tc estimation is essential for the implementation of control structures. In rural areas, it also helps the farmers to identify the most appropriate area for crops, based on the evaluation of the flood risk, which totally depends on a good estimation of the watershed tc.

\section{ACKNOWLEDGEMENTS}

The current work has been supported by the Laboratory of Applied and Environmental Hydrology (LABHA) at ESALQ/USP. We kindly acknowledge the Tropical Water Research Alliance, particularly the branch of the State of Sao Paulo, for promoting the research collaboration among the associate members.

\section{REFERENCES}

Almeida, I.K., Almeida, A.K., Anache, J. A. A., Steffen, J. L., and Sobrinho, T.A., 2014. Estimation on time of concentration of overland flow in watersheds: a review. Geociências, 33(4), 661-671. 
Araujo, B.A.M.D., Silveira, C.S., Souza, J.L., Maia Junior, J.V.F., Almeida, F.A.F., Studart, T.M.C., 2011. Análise do Tempo de Concentração em Função das Características Fisiográficas em Bacias Urbanas. In: XIX Simpósio Brasileiro de Recursos Hídricos, 2011, Fortaleza, 1-18.

Boulomytis, V.T.G., Zuffo, A.C., Imteaz, M.A., Herrrera, M.A.C., 2017. The effectiveness of the CN method in areas with saturated soil conditions. In: 22nd International Congress on Modelling and Simulation (MODSIM2017), 2017, Hobart, 1, 1663-1669.

Chow, V.T., 1962. Hydrologic determination of waterway areas for the design of drainage structures in small drainage basins. Engineering Experiment Station Bulletin n.462. Urbana, In: University of Illinois College of Engineering, $104 \mathrm{p}$.

Dooge, J.C.I., 1656. Synthetic unit hydrographs based on triangular inflow. Iowa State University,103 p.

Esteves, R.L. Mendiondo, E.M., 2003. Análise comparativa entre equações e observações do tempo de concentração em uma bacia urbana de Sao Carlos, SP. In: XV Simpósio Brasileiro de Recursos Hídricos, 2003, Curitiba.

Kirpich, Z.P., 1940. Time of concentration in small agricultural watersheds, Civil Engineering, 10(6).

Maia, J.C.P., 2020. Tempo de concentração em três bacias hidrográficas de Uberlândia, Minas Gerais. 48 f. Universidade Federal de Uberlândia, Uberlândia.

Mapbiomas, 2020. Projeto MapBiomas - Coleção 5 da Série Anual de Mapas de Cobertura e Uso de Solo do Brasil. Available at https://mapbiomas.org/colecoes-mapbiomas-br. Accessed on 10 Apr. 2021.

Mccuen, R.H., Wong, S.L., Rawls, W.J., 1984. Estimating urban time of concentration. Journal of Hydraulic Engineering, 110(7), 887-904.

Moraes, I.C., Correa, E.A., Conceição, F.T., 1994. Análise da fragilidade ambiental utilizando técnicas em SIG: estudo de caso da bacia hidrográfica do córrego do Desemboque, Pirassununga -SP -Brasil. In: Simpósio Nacional de Geomorfologia, Brasília. Available at http://lsie.unb.br/ugb/sinageo/8/10/9.pdf. Acessed on 25 May 2021.

Nasiri, A., Alipur, H., 2014. Determination the Curve Number catchment by using GIS and remote sensing. International Journal of Geological and Environmental Engineering, 8(5), 342-345.

Pissarra, T. C. T., Politano, W., Ferraudo, A. S., 2004. Avaliação de características morfométricas na relação solo-superfície da bacia hidrográfica do córrego Rico, Jaboticabal (SP). Revista Brasileira de Ciência do Solo, 28.

Raminhos, C, 2002. Experimentação e análise de resistência ao escoamento com macrorugosidades. Évora: Universidade de Évora. (Report).

Silveira, A. L. L., 2005. Desempenho de fórmulas de tempo de concentração em bacias urbanas e rurais. RBRH: revista brasileira de recursos hídricos, 10(1), 5-23.

Targa, M. D. S; Batista, G. T; Diniz, H. N; Dias, N. W; Matos, F. C., 2012. Urbanização e escoamento superficial na bacia hidrográfica do Igarapé Tucunduba, Belém, PA, Brasil. Revista Ambiente \& Água, $7(2), 120-142$.

Tucci, C. E. M., 2009. Hidrologia: Ciência e Aplicação. 4 ed, Porto Alegre- RS:UFRG. 